\author{
Yevheniya Yuriychuk \\ Yuriy Fedkovych Chernivtsi National University \\ ORCID ID: https://orcid.org/0000-0002-5288-4827 \\ e-mail: y.yuriychuk@chnu.edu.ua.
}

\author{
Dmytro Antoniuk \\ Yuriy Fedkovych Chernivtsi National University \\ ORCID ID: https://orcid.org/0000-0002-3143-4464 \\ e-mail:d.antoniuk@chnu.edu.ua
}

\title{
Clientelism in the electoral process as a manifestation political corruption. Case of Ukraine
}

\footnotetext{
$\mathrm{n}$ the context of the political power and political system investigation in general, there is a definition of political corruption that takes place in the political sphere and poses an open threat to the democratic regime, especially at its initial stages, when political power institutions are weak and insufficient. Some corruption problems are observed directly during the election process, which usually include bribery of voters and establishment of clientelism within society, which further leads to inefficient government agencies and development of the highest level power corruption. The problem of political corruption investigationis of scientific interest, taking into account the state of democracy in today's Ukraine, and the refore among modern scholars on the subject, we should distinguish the works of the following domestic researchers: Halyna Kokhan ${ }^{1}$, Ihor Kushnaryov $^{2}$, Yevhen Nevmerzhytskyi ${ }^{3}$ and others. The work of the modern Norwegian researcher Inge Amundsen was also used ${ }^{4}$.Recently, there has been an intensification of research on electoral clientelism. To highlight the essence of clientelism in the electoral process the studies of modern foreign scientists of this phenomenon in societies with

1 H. Kokhan, Politychna koruptsiia yak naslidok konfliktu mizh derzhavoiu ta suspilstvom, "Naukovi zapysky [Instytutu politychnykh i etnohrafichnykh doslidzhenim. I. F. Kurasa]" 2008, № 42, s. 173-181.

2 I. Kushnarov, Politychna koruptsiia: porivnialno politolohichna kontseptualizatsiia, Kyiv 2018.

3 Y. Nevmerzhytskyi, Politychna koruptsiia: sutnist, zmist, mekhanizmy protydii, "Pravo Ukrainy" 2008, № 7, s. 123-130.

4 I. Amundsen, Political corruption, Bergen 2006, [online], https://www.u4.no/publications/political-corruption.pdf, inf. 20 IV 2021.
} 
weak democracies were used: Eric Kramon ${ }^{5}$, Paula Muñoz ${ }^{6}$, Simeon Nichter ${ }^{7}$, Mariela Szwarcberg ${ }^{8}$; societies of transitional democracy 9 : András Sajó, Mark Philp, Edgard Blankenburgand others. As a promising experience to study clientelism in the post-Soviet period the works of such scholars as Isabela Mares, Aurelian Muntean, Tsveta Petrova, Lauren E. Young on the application analysis of clientelistic strategies and voters' behavior in Bulgaria, Romania and Hungary ${ }^{10}$ are worth mentioning. However, the experience of Ukrainian election campaigns in this perspective has not been sufficiently studied, especially after the adoption of the Electoral Code of Ukraine.

THE AIM of the ARTICLE is to determine the essence of political corruption and clientelism in the electoral process and their interrelationship.

\section{Theoretical aspects of the connection between electoral clientelism and political corruption}

Political corruption is a rather broad concept, so, in view of the purpose of our study, we appropriately refer to directly political definitions, since very often "political corruption" is considered a corruption activity in state administration as well, although both approaches complement each other, which allows us to better understand this phenomenon. According to modern British scientist M. Philip, political corruption can only exist in the presence of political power. Therefore, political corruption should be considered as one of the means of undermining the system of political governance, which in turn will create obstacles to the introduction of favorable conditions for the society's existence ${ }^{11}$. Also, political corruption is seen synonymous with the so-called "grand corruption" or corruption in the highest echelons of power, where policy is formed and important political decisions are adopted ${ }^{12}$. So, politicians, government ministers, and senior government officials are involved in political corruption. I. Amundsen defines political corruption as the political elites' abuse of public resources, which they manage, to maintain their political power. Thus, political corruption includes two interdependent processes: the use of political power for personal gain and the use of accumulated resources to bribe

5 E. Kramon, Money for Votes: The Causes and Consequences of Electoral Clientelism in Africa, Cambridge 2017.

6 P. Muñoz, Buying Audiences: Clientelism and Electoral Campaigns When Parties Are Weak, Cambridge 2018.

7 S. Nichter, Votes for Survival: Relational Clientelism in Latin America, Cambridge 2018.

8 M. Szwarcberg, Mobilizing Poor Voters: Machine Politics, Clientelism, and Social Networks in Argentina, Cambridge 2015.

9 Politychna koruptsiia perekhidnoi doby, red. S. Kotkin, A. Shaio, Kyiv 2004.

10 I. Mares, A. Muntean, T. Petrova, Economic Intimidation in Contemporary Elections: Evidence from Romania and Bulgaria, "Government and Opposition", page 1 of 32. DOI: 10.1017/gov.2016.39; Mares I., Young L. E. The Core Voter's Curse: Clientelistic Threats and Promises in Hungarian "Elections Comparative Political Studies" 2018, Vol. 51(11) 1441-1471. DOI: 10.1177/0010414018758754.

11 Politychna koruptsiia perekhidnoi doby, s. 53.

12 U4 Anti-Corruption Resource Centre, Political corruption, [online], https://www.u4.no/terms\#political-corruption, inf. 24 II 2020. 
voters; the rules of formation and use of election funds negation; campaigning and creating a positive image with the aim of winning the election, receiving power etc. ${ }^{13} \mathrm{Here}$, it is useful to recall the definition of a Ukrainian financier I. Kushnaryov, who believes that political corruption is a "destructive informal institution of particular character, which stipulates for the misuse of the power resources by subjects of the political process in outside society interests, privatization of public resources under conditions of formal and constructive informal institutions' weakness ${ }^{14}$. E. Nevmerzhytskyi defines political corruption as a set of different in content and degree illegal actions that are carried out to achieve political goals, significantly affect the formation and functioning of government bodies, their adoption and implementation of political decisions ${ }^{15}$. H. Kokhan argues that political corruption is "an independent type of corrupt actions in the field of distribution of power, resources or political decision-making"16. Also, political corruption is understood as the act committed by the officials, improperly using their status to obtain certain benefits for themselves for purposes that violate the rights of others ${ }^{17}$.

The introduction of political corruption in the highest echelons of power inevitably leads to poor governance, unreasonable political decisions, lack of transparency and accountability in the work of government agencies, the creation of inefficient governance institutions, and so on. Corrupt use of political power also involves various manipulations with supervision and control institutions, creating a so-called "impunity syndrome" in which corruption offenses are not artificially curtailed. Lack of responsibility destroys the political will of managers to address corruption objectively, and therefore corrupt high-ranking officials are ready to firmly defend their influence and enrichment channels ${ }^{18}$.

Since under a democratic regime there is no alternative way of forming representative bodies of power other than the people's will, political corruption is most pronounced during the election process. In newly created democracies, where social uncertainty prevails, voters usually evaluate candidates for their ability to meet financial needs and deliver material goods. It is possible that some voters are counting on direct cash payments from candidates. This problem arises when states are unable to satisfy the voters' needs, for instance, guarantee the due level of remuneration. As a result, the voting acquires the forms of clientelistic relationships, forcing people to seek help not from the state, but the powerful political elite, having an access to the necessary resources ${ }^{19}$.

13 I. Amundsen, op. cit.

14 I. Kushnarov, op. cit., s. 90.

15 Y. Nevmerzhytskyi, Politychna koruptsiia: sutnist, zmist, mekhanizmy protydii, "Pravo Ukrainy" 2008, № 7, s. 129.

16 H. Kokhan, op. cit., s. 173.

17 A. Tinkov, Politychna koruptsiia v systemi derzhavnoho upravlinnia: ukrainski realii, "Visnyk Natsionalnoi akademii derzhavnoho upravlinnia pry Prezydentovi Ukrainy” 2010, № 1, s. 230.

18 I. Amundsen, op. cit.

19 U4 Anti-Corruption Resource Centre, Clientelism, [online], https://www.u4.no/terms\#clientelism, inf. 29 IV 2021. 
According to the British Encyclopedia, clientelism is a "relationship between persons of different economic and social status (between "patron" and "client"), which entails the mutual exchange of goods and services on the basis of personal communication usually perceived from the point of view of moral obligation ${ }^{20}$. However, talking about clientelism in the electoral process, where the "patron" can be both a single politician and a separate political party, and "clients" are voters, the term acquires a new meaning, which in scientific literature is called "electoral clientelism". Electoral clientelism is usually understood as material goods provision in exchange for support during elections, where voters benefit only on the eve of voting ${ }^{21}$. P. Muñoz considers electoral clientelism a strategy of voters' mobilization, according to which the politician offers personal benefits (money, services) to individuals in exchange for electoral support ${ }^{22}$. Sarah Birch identifies electoral clientelism as a mechanism that replaces individual benefits with collective ones, for which voters' inclinations are exchanged ${ }^{23}$. E. Kramon underlines, that this is a mechanism for the future, since with its help politicians send signals to voters about the future benefits of clientelistic nature in case of their election in order to gain support in the election ${ }^{24}$.

Usually electoral clientelism exists in those democratic countries, where there is a need to mobilize significant amount of voters. It is due to the fact, that political parties need time to form political reputation. Until party identification is formed, voters' activities can be influenced by regional sentiments, ethnic identity, particularism etc. Without society's unity, "unfair" politicians will surely take advantage of this fact by offering privileges to one group at the expense of another, more widening the disparity ${ }^{25}$. According to F. Fukuyama, it's these reasons, which caused clientelism to become the earliest form of encouraging US citizens to participate in democratic processes of the political system. In authoritarian states, where elections are nothing but a fiction, and the winner is determined in advance, clienteleism can be used in the same way to ensure high turnout. The only difference is that under authoritarian regimes it is easier to resort to clientelistic strategies, as there is no proper control over the authorities, and the political sphere is often fused with the bureaucracy. Although the fulfillment of election promises is the main task of politicians, giving an improper advantage to one group at the expense of another can deepen inequality within society, and further to conflict. Accordingly, clientelism should be seen as a deviation from democratic practices, since in modern democracies, citizens have to vote on the basis of politicians'

20 Britannica, Clientelism, [online], https://www.britannica.com/topic/clientelism, inf. 22 V 2020.

21 S. Nichter, op. cit., p. 11.

22 P. Muñoz, op. cit., p. 22.

23 S. Birch, Nomenklatura democratization: Electoral clientelism in post-soviet Ukraine, "Democratization" 1997, vol. 4 (4), p. 41.

24 E. Kramon, Money for Votes: The Causes and Consequences of Electoral Clientelism in Africa, Cambridge 2017, p. 11.

25 J.S. You, Democracy, Inequality and Corruption: Korea, Taiwan and the Philippines Compared, Cambridge 2015, p. 123. 
promises of the overall public benefit. Thus, the elections should reflect the general opinion of what will be really useful for the whole community, and not for an individual or group ${ }^{26}$.

Jong-sung You in dicatesina dequate economic development of the country and inadequate level of education as the main reasons of electoral clientelism appearance ${ }^{27}$. If there is a significant inequality between the rich and the poor within society, the corrupt competition between parties is increasingly probable, while the competition based on election programs de facto becomes a formality. When politicians "buy" low-income voters, they ignore the real political preferences of poor people; inhibit their ability to express their wishes in collective decision-making, and, as a result, political equality is violated $^{28}$. It is clear that such politicians do not want to represent the interests of the poor, focus on improving their situation, as these steps will make it impossible to use clientelistic strategies in future elections, and people with financial problems are easier to be manipulated and, therefore, easier to be bribed, deceived etc.

As inequality among the population increases, the democratic elite will fear the emergence of left-wing parties and their rapid growth, and will therefore have an incentive to buy votes from the poor. On the other hand, a large number of the poor, due to their difficult situation, tend to exchange their votes for some short-term benefit. Thus, electoral clientelism in uneven societies develops faster, while program competition between political parties is difficult to develop. Gradually clientelism becomes so commonplace that corrupt candidates always win elections. And the more poor people live in the country, the more voters can be mobilized, but the costs of mobilization will be significant, and once in power, it will encourage the politicians immediately return their bribes at the expense of the state budget. It is difficult to oppose such "political machines", especially without sufficient funding ${ }^{29}$. Without program competition, elections lose their function as a mechanism for forming a national vector of development and become a competition for individual groups and classes. Regardless of the fact, that clientelism usually involves petty electoral corruption, the ability to resort to it by the political elite inevitably leads to the development of large-scale political corruption ${ }^{30}$.

It is a mistake to believe, that electoral clientelism is limited exclusively by buying votes. S. Nichter singles out six types of electoral clientelism used by dishonest politicians to gain an advantage during elections. The first type of corruption during the election process, the author identifies the above mentioned politician's bribing for the purpose of dragging voters to his side. This procedure can also be applied to voters with uncertain political preferences or indifferent to their choice. The next type of electoral

${ }^{26}$ F. Fukuyama, What is Corruption? [online], https://www.gov.uk/government/publications/againstcorruption-a-collection-of-essays/against-corruption-a-collection-of-essays\#francis-fukuyama-what-is-corruption, inf. 19 IV 2021.

27 J.S. You, op. cit., p. 124-125.

28 M. Szwarcberg, op. cit., p. 3.

29 Ibidem.

30 J.S. You, op. cit., p. 95. 
clientelism is the so-called turnout buying, which is used primarily to mobilize voters, when a political force or a candidate is confident in the political beliefs of their electors, but they do not have the required number of votes to win in the constituency. Another manifestation of electoral clientelism is the bribe of voters to encourage them to renounce their voting, in order to undermine the opponents' turnout and deprive them of victory. The next kind of electoral clientelism is the procedure, when electors change their voting registration to vote for a candidate in the constituency they do not belong to and, thus, giving the last an advantage in the election race. The type of clientelism is also worth mentioning, when candidates do not offer money to the electors in exchange for votes, but solution of their pressing problems in the district, and, in case of victory, do not keep promises, or reward a limited number of people. Finally, S. Nichter considers a situation, in which parties or an individual candidate rewardi their adherents on a regular basis for constant support in the election ${ }^{31}$.

E. Kramon, on the contrary, believes that politicians should not necessarily resort to bribery to build a clientelistic relationship with voters, but, above all, it is necessary to send them a clear message about their ability to meet the needs of voters in the long run, where monetary/material benefits will serve only as additional evidence of the politicians' broad possibilities ${ }^{32}$. In our view, this approach is justified, since there is a high probability that in societies with high levels of corruption, majority of politicians resort to bribery and voters will have to choose the worthiest among them, to their mind. As a result, the personal qualities of a politician come to the fore (the ability to deliver benefits has already been mentioned), and therefore the basis of electoral clientelism will be the information component, and only then the material one. Thus, electoral clientelism can be considered as one of the tools of the election campaign, where the offer of tangible/intangible benefits by politicians will be ineffective without direct interaction with voters ${ }^{33}$.

Today, in addition to the candidates and parties' program promises, a wide range of non-program means of influencing the electorate is used 1) to support / not to support a particular candidate or political force; 2) absence from elections or referendums. Among them are: firstly, incentive means / strategies; and, secondly, coercive (see Table 1). In different localities, electoral clientelism is manifested in many combinations of the above strategies, and the ability of politicians to use public resources during elections and to prefer the first or second type of strategy depends on the length of stay and variability frequency in the chosen position.

\footnotetext{
S. Nichter, op. cit., p. 28-30.

32 E. Kramon, op. cit., p. 11.

33 P. Muñoz, op. cit., p. 52.
} 
Table 1. Clientelistic strategies of influencing the electorate ${ }^{34}$

\begin{tabular}{|l|l|l|}
\hline $\begin{array}{c}\text { Groups of } \\
\text { strategies }\end{array}$ & \multicolumn{1}{|c|}{ Content } & \multicolumn{1}{c|}{ Means } \\
\hline Incentive & $\begin{array}{l}\text { Encouragement to vote } \\
\text { for a candidate or party } \\
\text { through the provision of } \\
\text { benefits and administra- } \\
\text { tive benefits }\end{array}$ & $\begin{array}{l}\text { Granting permits, licenses, preferential access to social } \\
\text { policy programs, social travel tickets, unemployment } \\
\text { benefits, land, jobs, payment of bonuses }\end{array}$ \\
\hline Coercive & $\begin{array}{l}\text { Coercion to vote for } \\
\text { a candidate or party due } \\
\text { to pressure and threats of } \\
\text { post-election punish- } \\
\text { ment }\end{array}$ & $\begin{array}{l}\text { Closure of farmers' organizations, cessation of bread sup- } \\
\text { plies, transport links, late payment of salaries, pensions, } \\
\text { scholarships, access to state infrastructure, public educa- } \\
\text { tion, medical services, goods market (EU), pressure from } \\
\text { regulatory and law enforcement agencies, non-refund of } \\
\text { VAT, restriction of access or deterioration of credit condi- } \\
\text { tions, mass recruitment to the party ranks of management } \\
\text { and workers of enterprises, educators, physical harm }\end{array}$ \\
\hline $\begin{array}{l}\text { Vote } \\
\text { buying }\end{array}$ & $\begin{array}{l}\text { Cash payments, provision of products, non-food items, } \\
\text { transportation to the polling station }\end{array}$ \\
\hline
\end{tabular}

The analysis of the above considerations allows us to define electoral clientelism as a mechanism for establishing interaction between voters and politicians to demonstrate the latter's ability to meet/dissatisfy the needs of voters in order to gain an advantage during the election process.

\section{Manifestation and counteraction to electoral clientelism: the example of Ukraine}

The use of various resources and levers of influence during the election campaign potentially allows using broad powers in favor of a particular candidate or political party, while creating unfavorable conditions for opponents. It is most effectively used in majority constituencies during the election campaign.

In Ukraine and in the post-Soviet space the term "administrative resource" is used to describe some of the above mentioned phenomena, which flourished during the presidential elections of 1999, 2004, parliamentary elections in 1998, 2002, the referendum of 2000, when one-fifth of the electorate came under such pressure, especially in the East. The most "brutal" forms of its manifestation prevailed, on the one hand pressure on voters through threats, bribery, violation of the secrecy of the ballot, and on the other - pressure on election commission members to falsify election results through blackmail and bribery, which was one of the causes of the Orange Revolution.

How can the above phenomena be counteracted?

${ }^{34}$ Compiled by the authors: I. Mares, A. Muntean, T. Petrova, op. cit.; I. Mares, L.E. Young, op. cit.; Practical experience of participation in election campaigns in Ukraine by the authors of the article E. Yuriychuk and D. Antoniuk. 
Their mass manifestations throughout the former USSR prompted the Venice Commission and the OSCE to develop and adopt Guidelines for election $s^{35}$ and referendums ${ }^{36}$. The interaction of the Council of Europe bodies - the Parliamentary Assembly, the European Court of Human Rights, the Venice Commission, the Group of States against Corruption (GRECO) and the documents adopted by them allow to build a strategy to combat political corruption, electoral clientelism and develop anti-corruption mechanisms. Clear tasks of the electoral process democratization and counteraction to electoral clientelism are set in Resolution 1897 (2012) ${ }^{37}$.

We consider electoral clientelism as a kind of political corruption that forms the basis for obtaining or maintaining power by a dishonest politician through the institution of democratic elections. To subjugate the spread of clientelistic relations can be one of the important steps towards overcoming political corruption. It is necessary to establish clear rules of an election campaign conduct, which, in particular, would prohibit the politicians to repair infrastructural objects, to deliver food packages to low-income voters etc., making their self-promotion, because these initiatives, in our opinion, distort the electoral process as competition of ideas and level a politician's assessment according to his professional qualities, whose activities in case of election are likely to threaten with the emergence of new corruption risks.

Nowadays electoral clientelism, in our opinion, serves as a clear indication that the politician will be ineffective after getting into office, since he cannot offer effective solutions to common problems, or long-term strategy for general development, sufficient to win the election, and the absence of proper anti-corruption control will facilitate a high probability of using his authority and public resources for his own purposes. That's why, clientelism, like political corruption, does not provide for the general public benefit and violates universal rights. Another question is: "Does society have a demand for a short-term benefit during the election process?" We see the solution of this issue in achieving a favorable economic and political situation within the country and proper training through the education system, through implementation of Recommendation $\mathrm{CM} / \mathrm{Rec}$ (2010)7 of the Committee of Ministers to member States on the Council of Europe Charter on Education for Democratic Citizenship and Human Rights Education, which will give opportunity to create a developed civil society, critical of politicians' "handouts" on the eve of the election.

Prevention of electoral clientelism is possible through strict control over the financing of election campaigns and parties, which the Council of Europe emphasizes. Such control is carried out in three directions:

- origin of election funds;

35 Code of Good Practice in Electoral Matters, Opinion No. 190/2002, Venice Commission, [online], https://www.venice.coe.int/webforms/documents/?pdf=CDL-AD(2002)023rev2-cor-e, inf. 29 IV 2021.

36 Code of Good Practice on Referendums, Opinion No. 190/2002, Venice Commission, [online], https:// www.venice.coe.int/webforms/documents/?pdf=CDL-AD(2007)008rev-cor-e, inf. 29 IV 2021.

37 Parliamentary Assembly, Resolution 1897 (2012), [online], https://assembly.coe.int/nw/xml/XRef/ Xref-XML2HTML-en.asp?fileid=19121\&lang=en, inf. 29 IV 2021. 
- setting the upper limit of costs;

- public control of the candidates and parties' funds movement for the election campaign ${ }^{38}$.

Does the election legislation and implementation practice in Ukraine meet these requirements?

Election campaigns in Ukraine are characterized by the use of "shadow" funds, mainly in foreign currency, that are not accounted for in the party's or candidate's election fund to bribe voters or members of election commissions. Through the formed network of "central" they are transferred for direct or indirect bribe of voters. While the election campaigns in Ukraine in the late XX and early XXI centuries mostly used pressure strategies, the 2012 parliamentary elections are an example of the witches' Sabbath demonstration, use of "black bookkeeping" to buy electors' votes, to pay high-ranking officials, to pay for political advertising, etc. for a total of $\$ 2$ billion $^{39}$.

At first glance, the Electoral Code of Ukraine contains the necessary instructions to control the receipts and use of state budget funds and election funds, primarily candidates for President of Ukraine ${ }^{40}$. The control function not only of the Central Election Commission (CEC), but also of the National Agency for the Corruption Prevention regarding the reporting on the use of funds (NACP) is especially emphasized ${ }^{41}$. Reports on the use of state budget funds in the elections of people's deputies of Ukraine are already sent not only to the CEC, state financial control bodies, the State Treasury Service of Ukraine ${ }^{42}$, but also to the Accounting Chamber ${ }^{43}$, but NACP carries out only the general control ${ }^{44}$. However, it carefully analyzes the reports of the deputies' election funds ${ }^{45}$. The most interesting provisions are contained in the section on local elections. Election funds are controlled not only by the Territorial Election Commission (TEC) ${ }^{46}$, but also by the financial authorities of the executive branch and the Accounting Chamber $^{47}$, but only the TEC analyzes the financial statements of election funds ${ }^{48 ! ! ! ~ N o t e, ~ t h a t ~}$ the form of the report proposed by the CEC is still agreed with the NACP. ${ }^{49}$. However, at the local level there is virtually no "control over the receipt, accounting and use of

\footnotetext{
38 Parliamentary Assembly, Resolution 1897 (2012).

39 Ukrinform. 29.07.2016 14:42. Chorna bukhhalteriya: Naybil'she «rehionaly» vytratylysya na vybory-2012 - ZMI, [online], https://www.ukrinform.ua/rubric-polytics/2058674-corna-buhgalteria-najbilse-regionali-vitratilisa-na-vibori2012-zmi.html.

40 Vyborchyy kodeks Ukrayiny vid 19 hrudnya 2019 r. № 396-IX, p. 9, s. 86, p. 10, s. 90, s. 94, [online], https://zakon.rada.gov.ua/laws/show/396-20\#Text.

41 Vyborchyy kodeks Ukrayiny, p. 6, s. 97. Ibidem, p. 10, s. 148.

42 Ibidem, p. 10, s. 148.

43 Ibidem, p. 18, s. 143.

${ }^{44}$ Ibidem, p. 14, s. 150.

${ }^{45}$ Ibidem, p. 8, s. 153.

${ }^{46}$ Ibidem, p. 13, s. 206.

47 Ibidem, p. 10, s. 210.

48 Ibidem, p. 8, s. 214.

49 Ibidem, p. 9, s. 214.
} 
election funds", as it is carried out selectively by TEC and bank institution, where the election fund account is opened ${ }^{50}$. In fact, anti-corruption bodies have nothing to do with the preliminary control in this area, except in cases of detected violations. I.e., there are no uniform requirements for the control of election funds at various levels, financial reporting and participation of anti-corruption bodies. Therefore, at the local level, where local budget funds accumulate as a result of decentralization, it is virtually impossible to counteract vote buying. These considerations complement the data on the regulation of election spending restrictions. The Code stipulates the upper limit of the election fund size of a candidate for People $\epsilon$ D Deputies - 4,000 times the minimum wage, set for January 1 st of the relevant year ${ }^{51}$. Maximum contributions to the presidential candidate's election fund are limited under the law "On Political Parties in Ukraine" 52 . In local elections, deputies' own funds and party contributions to the election campaign are not limited $^{53}$, and the contributions of individuals may not exceed 10 times the minimum wage $e^{54}$. There is no question of public control over funds.

Is it possible to punish agents of electoral clientelism in Ukraine?

In order for the law to be clearly enforced, any violation must be punished according to the appropriate sanction. Note, that if in the 90s of the XX century the financing of the election process was practically not controlled, since punishment for violating the law was not provided, then with the regulation of the relevant processes in legislation a mechanism of prosecution was gradually developed (constitutional, administrative, civil, criminal, disciplinary). However, violators have also developed a mechanism to avoid liability by delaying the trial etc. For example, despite four years of ongoing trial on Rostislav Bilyk in the case of bribe in local elections 2015, he again ran for the Chernivtsi City Council deputy in $2020^{55}$. Another case - the Chairman of the Electoral Commission in Odessa was detained in 2020 for organizing a vote-bribing network to vote for a particular candidate for the presidency in Odessa, against whom criminal proceedings were instituted for election crimes in $2015^{56}$. That is, the law and the judiciary do not limit the criminals' ability not only to perform the future complex duties of managing the election commission, but also to hold elected offices. In the light of the judicial system and constitutional justice crisis in Ukraine, in particular, it still seems

50 Ibidem, p. 9, c. 215.

51 Ibidem, s. 150.

52 Ibidem, s. 96.

53 Ibidem, p. 1, s. 215.

${ }^{54}$ Ibidem, p. 2, s. 215.

55 Chernivtsi: Chynnyy deputat mis'krady, yakyy ye pidsudnym u spravi pro pidkup vybortsiv, znovu balotuyet'sya $v$ deputaty. 28 veresnya 2020, [online], https://www.oporaua.org/news/vybory/mistsevi-vybory/mistsevi_2020/21027-chernivtsi-chinnii-deputat-miskradi-iakii-ie-pidsudnim-u-spravi-pro-pidkup-vibortsiv-znovu-balotuietsia-v-deputati/.

56 Departament stratehichnykh rozsliduvan' Natsional'noyi politsiyi Ukrayiny. 15-ho zhovtnya 2020. Ihor Klymenko: V Odesi politsiya vykryla «sitku» pidkupu vybortsiv, [online], https://mvs.gov.ua/ uk/press-center/news/Igor_Klimenko_V_Odesi_policiya_vikrila_sitku_pidkupu_viborciv_35135. 
impossible to implement the recommendations of the Council of Europe on electoral control by the judiciary.

The foreign practice shows other ways to minimize the impact of clientelism on the electoral process, in particular on preventing bribery, among which we can highlight the introduction of electronic voting, establishing compulsory voting, strict control over the funding of elections and referendums, improvement of election legislation on agitation campaign. In essence, a party or a candidate, when buying a vote, requires an elector to confirm his proper vote. Usually, such reporting takes the form of photographing the bulletin. Political parties and individual candidates could control in such a way the bribed citizens, and, therefore, violate the secrecy principle of voting. During the presidential election of 2019, despite the official warning of the adviser to the Minister of Internal Affairs I. Varchenko about severe sanctions and responsibility of participants in the election process, as far as on March 18, 449 applications were received and 54 criminal cases for vote bribing were opened (art. 160 of the Criminal Code) and 4 - for violation of the procedure for a political party financing ... (159-1) $)^{57}$.

Only during the last local elections in Ukraine in 2020, 274 violations of the ballot secrecy were recorded, 42 administrative protocols were drawn up on public disclosure of the expression of will results by a participant in the election process (art. 212-22 of the Code of Administrative Offenses) ${ }^{58}$, 4 criminal proceedings were initiated on the ballot secrecy (art. 159, Criminal Code) ${ }^{59}, 21$ criminal proceedings for vote bribing (art. 160, Criminal Code $)^{60}$. Other violations include illegal destruction of election documents (181), violation of the procedure for maintaining voter registers or voter lists (178), illegal use of the ballot (attempt or carrying out of a ballot) $(102)^{61}$. In addition, the Ministry of Internal Affairs reported the discovery of a whole network of vote buying in the most important cities for the government - the customs center of counterfeit products - Odessa ${ }^{62}$

57 Departament komunikatsiyi MVS Ukrayiny. Selfi v kabinkakh dlya holosuvannya z byuletenyamy porushennya: MVS nahaduye pro tayemnytsyu holosuvannya, https://mvs.gov.ua/uk/press-center/ news/Selfi_v_kabinkah_dlya_golosuvannya_porushennya_Zakonu_U_MVS_nagadali_pro_tamnicyu_golosuvannya_19196.

58 MVS Ukrayiny. 26 oktyabrya 2020 h. \#MistseviVybory2020: Za den' holosuvannya politseys'ki vidkryly 159 kryminal'nykh provadzhen' za faktamy porushen' pid chas vyboriv. 26 zhovtnya $2020 \mathrm{r}$. [online], https://www.facebook.com/mvs.gov.ua/photos/pcb.3444951765591490/3444951392258 194; Kodeks Ukrayiny pro administratyvni pravoporushennya № 80731 (statti 1 - 212-24) https:// zakon.rada.gov.ua/laws/show/80731-10\#Text.

59 Ibidem.

${ }^{60}$ Ibidem.

${ }^{61}$ Ibidem; Kryminal'nyy kodeks Ukrayiny vid 5 kvitnya 2001 roku № 2341-III, [online], https://zakon. rada.gov.ua/laws/show/2341-14\#Text.

62 Departament stratehichnykh rozsliduvan' Natsional' noyipolitsiyi Ukrayiny. 15-hozhovtnya 2020. IhorKlymenko: VOdesipolitsiyavykryla «sitku» pidkupuvybortsiv, [online], https://mvs.gov.ua/uk/ press-center/news/Igor_Klimenko_V_Odesi_policiya_vikrila_sitku_pidkupu_viborciv_35135. 
and the capital - Kyiv ${ }^{63}$, as well as in Kirovograd region ${ }^{64}$, Boryspil ${ }^{65}$. However, if in the first two cities the cost of one vote was UAH 1,000. (30€), then in Central Ukraine and other regions, on average, it ranged from 400-500 UAH (12-16€).

Vote bribing was observed everywhere in the regions, but the official statistics were many times lower than the public organizations data and observations. Note the diversity of both the objects of bribery and the subjects and methods. In particular, in Mykolayiv policemen recorded the video address through the Facebook, appealing to take part in a certain political party actions for a monetary reward ${ }^{66}$. If in Donetsk region a candidate offered food kits to low-income elderly voters in support of his election as chairman of the united territorial community, in Bukovyna candidates for Kelmenets village and Dniester district councils were already buying votes of land share owners ${ }^{67}$. A detailed list of campaign restrictions in the Electoral Code (art. 57) is not a significant obstacle in the way of violation. Thus, during the local elections of 2021 in Chernivtsi, the "Sole Alternative" party representatives, together with advertising materials, distributed disposable medical masks, which was perceived as appropriate in a pandemic situation.

The introduction of harsh penalties for participating in clientelistic relations is also likely to give a positive result. For participation in clientelistic relations, namely for bribing a voter, an election commission or a referendum commission member, the Criminal Code (art. 160) ${ }^{68}$ provides for a rather severe punishment at least a fine of 300 to 400 tax-free minimum incomes, and as a maximum sanction - freedom deprivation for a term of 5 to 7 years with deprivation of the right to hold certain positions or to be engaged in certain activities for a term of five years ${ }^{69}$. Articles $158-159$ are relevant to

${ }^{63}$ Departament stratehichnykh rozsliduvan' Natsional'noyi politsiyi Ukrayiny. U Kyyevi politsiya vykryla osib v orhanizatsiyi «sitky» pidkupu vybortsiv, [online], https://mvs.gov.ua/uk/press-center/ news/U_Kivi_policiya_vikrila_osib_v_organizacii_sitki_pidkupu_viborciv_35408, inf. 29.04.2021.

64 Zamaterialamy slidchoho upravlinnya politsiy i Kirovohrads'koyioblasti. 24-hozhovtnya 2020. $\mathrm{Na}$ Kirovohradshchyni pravookhorontsi vykryly merezhu pidkupu vybortsiv, [online], https://mvs.gov. ua/uk/press-center/news/Na_Kirovogradshchini_pravoohoronci_vikrili_merezhu_pidkupu_viborciv_35495.

65 Viddil komunikatsiy I politsiyi Kyyivs'koyi oblasti. 24-hozhovtnya 2020. Politsiya Kyyivshchyny vstanovyla osobu cholovika, yakyy u misti Boryspil' orhanizuvav merezhu pidkupu vybortsiv, [online], https://mvs.gov.ua/uk/press-center/news/Policiya_Kiivshchini_vstanovila_osobu_cholovika_yakiy_u_misti_Borispil_organizuvav_merezhu_pidkupu_viborciv_35486.

${ }_{66}$ Viddil komunikatsiyi politsiyi Mykolayivs'koyioblasti. 22-hozhovtnya 2020. Politsiya vidkryla kryminal'ne provadzhennya shchodo mozhlyvoho pidkupu vybortsiv u Mykolayevi, [online], https://mvs. gov.ua/uk/press-center/news/Policiya_vidkrila_kriminalne_provadzhennya_shchodo_mozhlivogo_pidkupu_viborciv_u_Mikolavi_35384.

67 Viddil komunikatsiyi politsiyi Chernivets'koyi oblasti. 8-ho zhovtnya 2020. Na Bukovyni politsiya rozsliduye ymovirnyy pidkup vybortsiv, [online], https://mvs.gov.ua/uk/press-center/news/Na_Bukovini_policiya_rozslidu_ymovirniy_pidkup_viborciv_34910.

68 Kryminal'nyy kodeks Ukrayiny vid 5 kvitnya 2001 roku № 2341-III, [online], https://zakon.rada.gov. ua/laws/show/2341-14\#Text.

69 Ibidem. 
it, but it is too early to talk about the positive results of their application, because there is no systematic counteraction to political corruption due to "lack of political will at the highest level, usually from the side of political powers in office."70 It is a question, whether they should observe the law and provide equal conditions for all candidates in Ukraine.

The introduction of electronic voting will not only reduce control over the corrupt candidates and political forces, but also greatly simplify the vote-counting procedure ${ }^{71}$. Implementation of compulsory voting procedure, like in Belgium, Bulgaria, Luxemburg, Cyprus and Greece, has as its aim, above all, preventing bribery of voters, encouraging them not to vote for a particular candidate, and the election boycott. In addition, when all citizens have to cast their ballots in the elections, the corrupt candidates will not be sure of their victory, because it is too expensive to buy most of the votes ${ }^{72}$.

However, in the conditions of hybrid aggression against the Ukrainian state, we consider its implementation premature, but promising, on condition that proper cyber defense is provided.

\section{Conclusions}

Electoral clientelism is a form of political corruption used by unscrupulous politicians to gain and maintain power in a democratic society through the institution of elections. As a result of such distorted use, elections lose their significance as a competition of ideas, as they open the way to public funds for those who are not interested in providing broad public goods. Thus, electoral clientelism provokes the development of even greater corruption, which without proper control threatens the overall development of society.

Combating political corruption involves the imposition of severe sanctions and fair punishment for participation in clientelistic relations, in particular to ensure their inevitability to consolidate within society a sense of responsibility for the choice and education of civic culture.

In our opinion, preventing participants in clientelistic relations from participating in election campaigns as members of election bodies, candidates, observers and preventing them from holding political positions will be an effective tool for deterring corruption risks in the election process, which, in turn, requires the introduction of a quality mechanism for monitoring their implementation, and it's still a serious problem in modern Ukraine.

70 Parliamentary Assembly, Resolution 1897 (2012).

71 S. Nichter, op. cit., p. 37-38.

72 Ibidem, p. 48. 


\begin{abstract}
Authors consider political corruption and clientelism in the electoral process as destructive phenomena that violate the normal principle of society and artificially create obstacles within the political system. The understanding of clientelism by different authors as a component of political corruption, the conditions of its existence, as well as the consequences and influence on political power are analysed.

Basing on the achievements of foreign scientists, the content and the essence of the concept of "electoral clientelism" is determined, the main reasons and preconditions of this phenomenon emergence are found, the authors' own definition, summarizing the known scientific approaches, is offered. The devastating impact of clientelism on the electoral process that results in violating the principle of competition between political forces, and further leads to the development of corruption in the power system, is elucidated. Varieties of electoral clientelism in accordance with the tasks set by corrupt subjects of the electoral process in order to gain an advantage over opponents during the voting are found out. Apart from the approach, where electoral clientelism provides material benefits to voters, an approach, where the voters are constantly informed of the clientele character data, basing on which the unfair politicians create a mobilization campaign, is considered. The authors showed their own vision of the connection between electoral clientelism and political corruption manifested in the occupation of political positions by ineffective candidates and further use of their powers for private purposes, which will threaten the long-term prospects of social development. A number of ways to regulate clientelism's impact on the electoral process, in particular through electronic voting introduction, established compulsory voting, agitation campaign financing control, severe penalties for clientele activity etc., are traced.
\end{abstract}

Keywords: political corruption, clienteleism, electoral clienteleism, bribe of voters

\title{
Klientelizm w procesie wyborczym jako wyraz korupcji politycznej (przykład Ukrainy)
}

Streszczenie: Autorzy rozpatrują korupcję polityczną i klientelizm w procesie wyborczym jako zjawiska destrukcyjne, naruszające zasady życia społeczeństwa i tworzące sztuczne przeszkody w ramach systemu politycznego. W artykule przeanalizowano pojęcie "klientelizmu” jako składnika korupcji politycznej, warunki jego istnienia, a także konsekwencje wywierania wpływu na władzę polityczną. W oparciu o dorobek zagranicznych naukowców określono treść i istotę pojęcia „klientelizmu wyborczego", wyjaśniono główne powody i warunki wstępne do pojawienia się tego zjawiska oraz zaproponowano własną autorską definicję jako podsumowanie analizy dobrze znanych podejść naukowców. Podkreślono destrukcyjny wpływ klientelizmu na proces wyborczy, w wyniku którego naruszono zasadę konkurencji między siłami politycznymi, co dodatkowo prowadzi do rozwoju korupcji w systemie władzy. Rodzaje klientelizmu wyborczego określono zgodnie z zadaniami stawianymi przez skorumpowane podmioty procesu wyborczego w celu uzyskania przewagi nad przeciwnikami podczas głosowania.

Oprócz podejścia, w którym klientelizm wyborczy przewiduje dostarczanie wyborcom korzyści materialnych, analizie poddano również podejście, w którym decydującą rolę odgrywa przekazywanie wyborcom informacji o charakterze klientelistycznym, w związku z czym nieskrupulatni politycy bu- 
dują kampanie mobilizacyjne. Podkreślona została autorska wizja związku klientelizmu wyborczego z korupcją polityczną, która przejawia się w zajmowaniu stanowisk politycznych przez nieefektywnych kandydatów z dalszym wykorzystywaniem tych stanowisk do celów prywatnych, co zagraża długoterminowym perspektywom rozwoju społecznego. Zidentyfikowano wiele sposobów regulowania wpływu klientelizmu na proces wyborczy, w szczególności przez wprowadzenie głosowania elektronicznego, a także przymusowego głosowania, kontrolę nad finansowaniem kampanii oraz surowe sankcje za udział w relacjach klientelistycznych itp.

Słowa kluczowe: korupcja polityczna, klientelizm, klientelizm wyborczy, przekupstwo wyborców

\section{Клиентелизм в избирательном процессе как проявление политической коррупции. Пример Украины}

Аннотация: Авторы рассматривают политическую коррупцию и клиентелизм в избирательном процессе как деструктивные явления, нарушающие нормальный принцип жизнедеятельности общества и создающие искусственные препятствия внутри политической системы. Проанализированы понимания клиентелизма различными авторами как составляющей политической коррупции, условия его существования, а также последствия влияния на политическую власть. Опираясь на наработки зарубежных ученых, определено содержание и суть понятия «электоральный клиентелизм», выяснены основные причины ипредпосылки возникновения этого феномена, предложено собственное авторское определение, которое обобщает известные подходы ученых. Освещено разрушительное воздействие клиентелизма на избирательный процесс, в результате которого нарушается принцип конкуренции между политическими силами, что в дальнейшем приводит к развитию коррупции в системе власти. Определены виды электорального клиентелизма в соответствии с задачами, которые перед собой ставят коррумпированные субъекты избирательного процесса для получения преимущества над оппонентами во время голосования. Кроме подхода, где электоральный клиентелизм предусматривает предоставление материальной выгоды избирателям, рассмотрен подход, при котором решающую роль играет трансляция избирателям информации клиентелистского характера, на основе которой недобросовестные политики строят мобилизационные кампании. Освещено авторское видение связи электорального клиентелизма с политической коррупцией, которая проявляется в занятии политических должностей неэффективными кандидатами с последующим использованием ими своих полномочий в личных целях, что грозит долгосрочным перспективам общественного развития. Определен ряд путей урегулирования влияния клиентелизма на избирательный процесс, в частности путем внедрения электронного голосования, установления обязательного голосования, контроля за финансированием агитационной кампании и внедрения строгих санкций за участие в клиентелистских отношениях и т. п.

Ключевые слова: политическая коррупция, клиентелизм, электоральный клиентелизм, подкуп избирателей. 


\section{Bibliografia}

1. Amundsen I., Political corruption, Bergen 2006, [online], https://www.u4.no/publications/political-corruption.pdf, inf. 20 IV 2021.

2. Birch S., Nomenklatura democratization: Electoral clientelism in post-soviet Ukraine, "Democratization" 1997, vol. 4(4), pp. 40-62. DOl: https://doi.org/10.1080/13510349708403535.

3. Britannica, Clientelism, [online], https://www.britannica.com/topic/clientelism, inf. 22 V 2020.

4. Chernivtsi: Chynnyy deputat mis'krady, yakyy ye pidsudnym u spravi pro pidkup vybortsiv, znovu balotuyet'sya v deputaty. 28 veresnya 2020, [online], https://www.oporaua.org/news/vybory/mistsevi-vybory/mistsevi_2020/21027-chernivtsi-chinnii-deputat-miskradi-iakii-ie-pidsudnim-u-spravipro-pidkup-vibortsiv-znovu-balotuietsia-v-deputati/, inf. 29 IV 2021.

5. Code of Good Practice in Electoral Matters, Opinion No. 190/2002, Venice Commission, [online], https://www.venice.coe.int/webforms/documents/?pdf=CDL-AD(2002)023rev2-cor-e, inf. 29 IV 2021.

6. Code of Good Practice on Referendums, Opinion No. 190/2002, Venice Commission, [online], https:// www.venice.coe.int/webforms/documents/?pdf=CDL-AD(2007)008rev-cor-e, inf. 29 IV 2021.

7. Departament komunikatsiyi MVS Ukrayiny. Selfi v kabinkakh dlya holosuvannya z byuletenyamy - porushennya: MVS nahaduye pro tayemnytsyu holosuvannya, [online], https://mvs.gov.ua/uk/ press-center/news/Selfi_v_kabinkah_dlya_golosuvannya__porushennya_Zakonu_U_MVS_nagadali_pro_tamnicyu_golosuvannya_19196, inf. 29 IV 2021.

8. Departament stratehichnykh rozsliduvan' Natsional'noyi politsiyi Ukrayiny. 15-ho zhovtnya 2020. Ihor Klymenko: V Odesi politsiya vykryla «sitku» pidkupu vybortsiv, [online], https://mvs.gov.ua/uk/press-center/news/Igor_Klimenko_V_Odesi_policiya_vikrila_sitku_pidkupu_viborciv_35135, inf. 29 IV 2021.

9. Departament stratehichnykh rozsliduvan' Natsional'noyi politsiyi Ukrayiny. U Kyyevi politsiya vykryla osib v orhanizatsiyi «sitky» pidkupu vybortsiv, [online], https://mvs.gov.ua/uk/press-center/ news/U_Kivi_policiya_vikrila_osib_v_organizacii_sitki_pidkupu_viborciv_35408, inf. 29 IV 2021.

10. Fukuyama F., What is Corruption? [online], https://www.gov.uk/government/publications/against-corruption-a-collection-of-essays/against-corruption-a-collection-of-essays\#francis-fukuyamawhat-is-corruption, inf. 19 IV 2021.

11. Kodeks Ukrayiny pro administratyvni pravoporushennya № 80731 (statti 1 - 212-24), [online], https://zakon.rada.gov.ua/laws/show/80731-10\#Text, inf. 19 IV 2021.

12. Kokhan H., Politychna koruptsiiayak naslidok konfliktum izhderzhavoiutasuspilstvom, "Naukovizapysky [Instytutu politychnykh i etnohrafichnykh doslidzhenim. I. F. Kurasa]" 2008, № 42. s. 173-181.

13. Kramon E., Money for Votes: The Causes and Consequences of Electoral Clientelism in Africa, Cambridge 2017.

14. Kryminal'nyy kodeks Ukrayiny vid 5 kvitnya 2001 roku № 2341-III, [online], https://zakon.rada.gov. ua/laws/show/2341-14\#Text, inf. 29 IV 2021.

15. Kushnarov I., Politychna koruptsiia: porivnialno politolohichna kontseptualizatsiia, Kyiv 2018.

16. Mares I., Muntean A., Petrova T., Economic Intimidation in Contemporary Elections: Evidence from Romania and Bulgaria, "Government and Opposition" 2016, vol. 53(3), pp. 486-517. D0I: https:// doi.org/10.1017/gov.2016.39.

17. Mares I., Young L.E., The Core Voter's Curse: Clientelistic Threats and Promises in Hungarian Elections, "Comparative Political Studies" 2018, vol. 51(11), pp. 1441-1471. D0I: 10.1177/ 0010414018758754. 
18. Muñoz P., Buying Audiences: Clientelism and Electoral Campaigns When Parties Are Weak, Cambridge 2018.

19. MVS Ukrayiny. 26 oktyabrya 2020 h. \#MistseviVybory2020: Za den' holosuvannya politseys'ki vidkryly 159 kryminal'nykh provadzhen' za faktamy porushen' pid chas vyboriv. 26 zhovtnya $2020 \mathrm{r}$. [online], https://www.facebook.com/mvs.gov.ua/photos/pcb.3444951765591490/34449513922 5819, inf. 29 IV 2021.

20. Kodeks Ukrayiny pro administratyvni pravoporushennya № 80731 (statti 1 - 212-24), [online], https://zakon.rada.gov.ua/laws/show/80731-10\#Text, inf. 29 IV 2021.

21. Nevmerzhytskyi Y., Politychna koruptsiia: sutnist, zmist, mekhanizmy protydii, "Pravo Ukrainy" 2008, № 7, s. 123-130.

22. Nichter S., Votes for Survival: Relational Clientelism in Latin America, Cambridge 2018.

23. Parliamentary Assembly, Resolution 1897, [online], https://assembly.coe.int/nw/xml/XRef/Xref-XML2HTML-en.asp?fileid=19121\&lang=en, inf. 29 IV 2021.

24. Politolohichnyi entsyklopedychnyi slovnyk, red. Y. Shemshuchenko, V. Babkin, V. Horbatenko, Kyiv 2004.

25. Politychna koruptsiia perekhidnoi doby, red. S. Kotkin, A. Shaio, Kyiv 2004.

26. Szwarcberg M., Mobilizing Poor Voters: Machine Politics, Clientelism, and Social Networks in Argentina, Cambridge 2015.

27. Tinkov A., Politychna koruptsiia v systemi derzhavnoho upravlinnia: ukrainski realii, "Visnyk Natsionalnoi akademii derzhavnoho upravlinnia pry Prezydentovi Ukrainy" 2010, № 1, s. 227-234.

28. U4 Anti-Corruption Resource Centre, Clientelism, [online], https://www.u4.no/terms\#clientelism, inf. 29 IV 2021.

29. U4 Anti-Corruption Resource Centre, Political corruption, https://www.u4.no/terms\#倓ical-corruption, inf. 24 II 2020.

30. Ukrinform. 29.07.2016 14:42. Chorna bukhhalteriya: Naybil'she «rehionaly» vytratylysya na vybory-2012 - ZMI, [online], https://www.ukrinform.ua/rubric-polytics/2058674-corna-buhgalteria-naj bilse-regionali-vitratilisa-na-vibori2012-zmi.html, inf. 29 IV 2021.

31. Viddil komunikatsiyi politsiyi Chernivets'koyi oblasti. 8-ho zhovtnya 2020. Na Bukovyni politsiya rozsliduye ymovirnyy pidkup vybortsiv, [online], https://mvs.gov.ua/uk/press-center/news/Na_Bukovini_policiya_rozslidu_ymovirniy_pidkup_viborciv_34910, inf. 29 IV 2021.

32. Viddil komunikatsiyi politsiyi Kyyivs'koyi oblasti. 24-ho zhovtnya 2020. Politsiya Kyyivshchyny vstanovyla osobu cholovika, yakyy u misti Boryspil' orhanizuvav merezhu pidkupu vybortsiv, [online], https://mvs.gov.ua/uk/press-center/news/Policiya_Kiivshchini_vstanovila_osobu_cholovika_yakiy_u_misti_Borispil_organizuvav_merezhu_pidkupu_viborciv_35486, inf. 29 IV 2021.

33. Viddil komunikatsiyi politsiyi Mykolayivs'koyi oblasti. 22-ho zhovtnya 2020. Politsiya vidkryla kryminal'ne provadzhennya shchodo mozhlyvoho pidkupu vybortsiv u Mykolayevi, [online], https://mvs. gov.ua/uk/press-center/news/Policiya_vidkrila_kriminalne_provadzhennya_shchodo_mozhlivogo_pidkupu_viborciv_u_Mikolavi_35384, inf. 29 IV 2021.

34. Vyborchyy kodeks Ukrayiny vid 19 hrudnya 2019 r. № 396-IX, [online], https://zakon.rada.gov.ua/ laws/show/396-20\#Text, inf. 29 IV 2021.

35. You J.S., Democracy, Inequality and Corruption: Korea, Taiwan and the Philippines Compared, Cambridge 2015. 
Pobrane z czasopisma Wschód Europy http://journals.umcs.pl/we

Data: 26/04/2023 17:13:59

36. Za materialamy slidchoho upravlinnya politsiyi Kirovohrads'koyi oblasti. 24-ho zhovtnya 2020. Na Kirovohradshchyni pravookhorontsi vykryly merezhu pidkupu vybortsiv, [online], https://mvs.gov. ua/uk/press-center/news/Na_Kirovogradshchini_pravoohoronci_vikrili_merezhu_pidkupu_viborciv_35495, inf. 29 IV 2021. 